\title{
Studies on the Effect of Different Sources of Potassium on Forms and Distribution, Release Kinetics and Fixation Characteristics in Alfisols
}

\author{
H. Vimalashree, M. Shivanna*, S. V. Patil, \\ P. Munikrishnappa and B. N. Maruthi Prasad \\ College of Horticulture, UHS campus, GKVK, Bengaluru, Karnataka, India \\ *Corresponding author
}

\begin{tabular}{|l|}
\hline Ke y w or d s \\
$\begin{array}{l}\text { Forms of potassium, } \\
\text { Alfisols }\end{array}$ \\
\hline Article Info \\
\hline $\begin{array}{l}\text { Accepted: } \\
\text { 10 November } 2020 \\
\text { Available Online: } \\
\text { 10 December } 2020\end{array}$ \\
\hline
\end{tabular}

\section{A B S T R A C T}

The investigation entitled Studies on the effect of different sources of potassium on forms and distribution, release kinetics and fixation characteristics in Alfisols was conducted during 2019-20 at UHS campus, College of horticulture, GKVK, Bengaluru. The experiment was laid out in RCBD with 8 treatments replicated thrice. Different sources of potassium (sulphate of potash, muriate of potash, potassium nitrate, Sulphate of Potash magnesia, Opifol maturation, Plantafol, Potassium schoenite and sulphate of potash magnesia) were applied at the rate of $63 \mathrm{~kg} \mathrm{ha}^{-1}$. The results revealed that treatment $\mathrm{T}_{2}$ contains high amount of WS-K and Exch-K in surface (14.84 and $\left.91.87 \mathrm{mgkg}^{-1}\right)$. In sub surface high amount NE-K and lattice-K (169.91 and $\left.3570.75 \mathrm{mgkg}^{-1}\right)$ and total-K in both surface $\left(3573.71 \mathrm{mgkg}^{-1}\right)$ and sub-surface $\left(4039.31 \mathrm{mgkg}^{-1}\right)$. The results showed that $\mathrm{T}_{2}: \mathrm{K}$ Supplied through sulphate of potash had recorded significantly high potassium fixation capacity in both surface $\left(0.53 \mathrm{meq} 100 \mathrm{gm}^{-1}\right.$ soil $)$ and sub-surface $\left(0.70 \mathrm{meq} 100 \mathrm{gm}^{-1}\right.$ soil). The potassium release was faster in the initial stage up to $5^{\text {th }}$ extraction and later it released less amount of $\mathrm{K}$ and finally reached constant by $10^{\text {th }}$ or $11^{\text {th }}$ extraction. The highest amount of total step $\mathrm{K}$ was recorded in the treatment which received sulphate of potash $\left(755 \mathrm{mgkg}^{-1}\right)$. The per cent contribution of different fractions of $\mathrm{K}$ to total-K were followed in the order of lattice-K ((92.18\%), NE-K (4.8\%), Exch-K (2.6\%) and WS-K $(0.42 \%)$ in surface.

\section{Introduction}

Potassium is the major nutrient and also a most abundant element in soil but the $\mathrm{K}$ content of the soil varies from place to place based on physico-chemical properties of soil. Potassium exist in soil in different forms viz., water soluble $\mathrm{K}$, exchangeable $\mathrm{K}$, nonexchangeable $\mathrm{K}$, mineral $\mathrm{K}$, lattice $\mathrm{K}$ and total $\mathrm{K}$ and these forms are heterogeneously distributed in soils. Its amount in soil depends on the parent material, degree of weathering, $\mathrm{K}$ gains through manures and fertilizers and losses due to crop removal, erosion and leaching. Usually the amounts of nonexchangeable $\mathrm{K}$ and total $\mathrm{K}$ present in the soil are high compared to water soluble $\mathrm{K}$ and exchangeable $\mathrm{K}$. The dynamics of potassium in soil depends on the magnitude of equilibrium among various forms and mainly governed by the physico-chemical properties of soil. The bulk of soil potassium (about $98 \%$ 
of total K) usually exists in unavailable form in primary (micas and feldspars) and secondary (illite group) clay minerals. The available $\mathrm{K}$ and exchangeable $\mathrm{K}$ in general are readily available to plants. The nature of the different forms of potassium equilibrium is variable and depends upon the soil type and nature of the clay minerals. The readily available $\mathrm{K}$ constitutes only 1 to 2 per cent of total $\mathrm{K}$ and exists in soil in two forms, viz., solution $\mathrm{K}$ and exchangeable $\mathrm{K}$ adsorbed on soil colloidal surface (Brady and Weil, 2002). These forms remain in dynamic equilibrium with one another. The readily available $\mathrm{K}$ or water soluble $\mathrm{K}$ has been reported to be a dominant fraction in the initial stage while, exchangeable $\mathrm{K}$ and non-exchangeable $\mathrm{K}$ contribute more in the later stages of crop growth. In many cases potassium can no longer be met by the supply from the soil. Potassium is so wandering in soil that its behavior under given situation is difficult to predict. In the view of the above facts, a very little or no information is available in relation to the dynamics of potassium in soils especially under vegetable cultivation. Hence the Studies on the effect of different sources of potassium on potassium fractions, its release and fixation character is carried out.

\section{Materials and Methods}

The experiment was conducted at research farm of College of Horticulture, Bengaluru, Bengaluru Urban district, which is situated in the eastern dry zone of Karnataka (Agro climatic Zone-5) state and situated at latitude of $\mathrm{N} 13^{0} 5^{\prime} 25.472$ " and at a longitude of $\mathrm{E}$ $77^{0} 33$ ' 40.605 ' and at an altitude of $1300 \mathrm{~m}$ above mean sea level (MSL). The experiment was laid out in RCBD with 8 treatments replicated thrice. The treatments comprised of $\mathrm{T}_{1}=$ Recommended dose of $\mathrm{K}$ supplied through Murate of potash, $\mathrm{T}_{2}=$ Recommended dose of $\mathrm{K}$ supplied through Sulphate of potash, $\mathrm{T}_{3}=$ Recommended dose of $\mathrm{K}$ supplied through Potassium nitrate, $\mathrm{T}_{4}=$
Recommended dose of $\mathrm{K}$ supplied through Sulphate of Potash magnesia, $\mathrm{T}_{5}=$ Recommended dose of $\mathrm{K}$ supplied through Opifol maturation, $\mathrm{T}_{6}=$ Recommended dose of $\mathrm{K}$ supplied through Plantafol, $\mathrm{T}_{7}=$ Recommended dose of $\mathrm{K}$ supplied through Potassium schoenite and $\mathrm{T}_{8}=$ Recommended dose of $\mathrm{K}$ supplied through Mono potassium phosphate.

Various forms of potassium were determined by flame photometer. Water soluble $\mathrm{K}$ Extracted by shaking soil and water suspension (1:5) for 1 hour and K determined on Flame Photometer (Black, 1965). Exchangeable $\mathrm{K}$ extracted by using $1 \mathrm{~N}$ neutral ammonium acetate, $\mathrm{K}$ on exchangeable complex determined with flame photometer (Knudsen et al., 1982). Nonexchangeable $\mathrm{K}$ determined by treating with 1 $\mathrm{N} \mathrm{HNO}_{3}$ in 1: 10 ratio and boiling for 10 minutes and $\mathrm{K}$ estimated with the help of flame photometer as described by Knudsen $e t$ al., (1982). Lattice K was calculated by subtracting the sum of above three fractions from the total potassium content. Total $\mathrm{K}$ extracted by HF digestion method (Jackson, 1973). The procedure suggested by Jackson (1973) was followed to determine potassiumfixing capacity of soils. The $\mathrm{K}$ release characteristics of soils were determined by employing successive extraction of soil with boiling $1 N \quad \mathrm{HNO}_{3}$ after removing exchangeable-K as per the method described by Haylock (1956).

\section{Results and Discussion}

Effect of different sources of potassium on potassium fractions, potassium release and fixation in soil. The availability of potassium to plant depends on relative mobility of the different forms of $\mathrm{K}$ in soil. Therefore, it is necessary to study the transformation of applied $\mathrm{K}$ in different forms in Alfisols (Table $1-3)$. 
Table.1 Forms and distribution of potassium in soils at different depths $(0-15 \mathrm{~cm}$ and $15-30 \mathrm{~cm})$ under okra as influenced by different sources of Potassium

\begin{tabular}{|c|c|c|c|c|c|c|c|c|c|c|}
\hline \multirow{3}{*}{ Treatments } & \multicolumn{2}{|c|}{ Water soluble-K } & \multicolumn{2}{|c|}{ Exchangeable-K } & \multicolumn{2}{|c|}{ Non exchangeable-K } & \multicolumn{2}{|c|}{ Lattice-K } & \multicolumn{2}{|c|}{ Total-K } \\
\hline & \multicolumn{10}{|c|}{$\left(\mathrm{mgkg}^{-1}\right)$} \\
\hline & $0-15 \mathrm{~cm}$ & $15-30 \mathrm{~cm}$ & $0-15 \mathrm{~cm}$ & $15-30 \mathrm{~cm}$ & $0-15 \mathrm{~cm}$ & $15-30 \mathrm{~cm}$ & $0-15 \mathrm{~cm}$ & $15-30 \mathrm{~cm}$ & $0-15 \mathrm{~cm}$ & $15-30 \mathrm{~cm}$ \\
\hline $\begin{array}{l}T_{1}: \text { K Supplied through Muriate } \\
\text { of potash }\end{array}$ & $\begin{array}{l}14.52 \\
(0.43)\end{array}$ & $\begin{array}{l}11.15 \\
(0.28)\end{array}$ & $\begin{array}{l}91.21 \\
(2.70)\end{array}$ & $\begin{array}{l}79.69 \\
(2.00)\end{array}$ & $\begin{array}{c}168.91 \\
(5.00)\end{array}$ & $\begin{array}{c}374.56 \\
(9.40)\end{array}$ & $\begin{array}{l}3103.57 \\
(91.87)\end{array}$ & $\begin{array}{c}3519.34 \\
(88.32)\end{array}$ & 3378.22 & 3984.77 \\
\hline $\begin{array}{l}\mathrm{T}_{2} \text { : K Supplied through Sulphate } \\
\text { of potash }\end{array}$ & $\begin{array}{l}14.84 \\
(0.42)\end{array}$ & $\begin{array}{l}11.71 \\
(0.29)\end{array}$ & $\begin{array}{l}91.87 \\
(2.60)\end{array}$ & $\begin{array}{l}81.12 \\
(2.01)\end{array}$ & $\begin{array}{c}169.61 \\
(4.80)\end{array}$ & $\begin{array}{c}375.65 \\
(9.30)\end{array}$ & $\begin{array}{r}3257.37 \\
(92.18)\end{array}$ & $\begin{array}{c}3570.75 \\
(88.40)\end{array}$ & 3533.71 & 4039.31 \\
\hline $\begin{array}{l}\mathrm{T}_{3}: \quad \mathrm{K} \quad \text { Supplied } \\
\text { Potassium nitrate }\end{array}$ & $\begin{array}{l}14.51 \\
(0.45)\end{array}$ & $\begin{array}{l}10.83 \\
(0.28)\end{array}$ & $\begin{array}{l}90.31 \\
(2.80)\end{array}$ & $\begin{array}{l}78.18 \\
(2.02)\end{array}$ & $\begin{array}{l}167.73 \\
(5.20)\end{array}$ & $\begin{array}{l}371.60 \\
(9.60)\end{array}$ & $\begin{array}{r}2953.03 \\
(91.55)\end{array}$ & $\begin{array}{l}3410.27 \\
(88.10)\end{array}$ & 3225.60 & 3870.91 \\
\hline $\begin{array}{l}T_{4}: K \text { Supplied through Sulphate } \\
\text { of potash magnesia }\end{array}$ & $\begin{array}{l}12.26 \\
(0.42)\end{array}$ & $\begin{array}{l}10.47 \\
(0.30)\end{array}$ & $\begin{array}{l}78.83 \\
(2.70)\end{array}$ & $\begin{array}{l}71.24 \\
(2.04)\end{array}$ & $\begin{array}{c}148.89 \\
(5.10)\end{array}$ & $\begin{array}{c}328.26 \\
(9.40)\end{array}$ & $\begin{array}{r}2679.45 \\
(91.78)\end{array}$ & $\begin{array}{c}3082.24 \\
(88.26)\end{array}$ & 2919.43 & 3492.23 \\
\hline $\begin{array}{l}T_{5}: \text { K Supplied through Opifol } \\
\text { maturation }\end{array}$ & $\begin{array}{l}13.28 \\
(0.44)\end{array}$ & $\begin{array}{l}10.54 \\
(0.29)\end{array}$ & $\begin{array}{l}87.59 \\
(2.90)\end{array}$ & $\begin{array}{l}73.07 \\
(2.01)\end{array}$ & $\begin{array}{c}160.08 \\
(5.30)\end{array}$ & $\begin{array}{c}334.46 \\
(9.20)\end{array}$ & $\begin{array}{r}2759.47 \\
(91.36)\end{array}$ & $\begin{array}{r}3217.39 \\
(88.50)\end{array}$ & 3020.44 & 3635.48 \\
\hline $\mathrm{T}_{6}: \mathrm{K}$ Supplied through Plantafol & $\begin{array}{l}14.48 \\
(0.44)\end{array}$ & $\begin{array}{l}10.88 \\
(0.28)\end{array}$ & $\begin{array}{l}88.86 \\
(2.70)\end{array}$ & $\begin{array}{l}79.32 \\
(2.04)\end{array}$ & $\begin{array}{c}167.84 \\
(5.10)\end{array}$ & $\begin{array}{c}373.31 \\
(9.60)\end{array}$ & $\begin{array}{l}3019.94 \\
(91.76)\end{array}$ & $\begin{array}{r}3425.14 \\
(88.08)\end{array}$ & 3291.13 & 3888.68 \\
\hline $\begin{array}{l}\mathbf{T}_{7}: \quad \mathrm{K} \quad \text { Supplied } \\
\text { Potassium schoenite }\end{array}$ & $\begin{array}{l}13.58 \\
(0.45)\end{array}$ & $\begin{array}{l}10.70 \\
(0.3)\end{array}$ & $\begin{array}{l}87.53 \\
(2.90)\end{array}$ & $\begin{array}{l}72.07 \\
(2.02)\end{array}$ & $\begin{array}{c}156.96 \\
(5.20)\end{array}$ & $\begin{array}{c}331.18 \\
(9.30)\end{array}$ & $\begin{array}{c}2759.96 \\
(91.45)\end{array}$ & $\begin{array}{r}3153.57 \\
(88.38)\end{array}$ & 3018.47 & 3568.20 \\
\hline $\begin{array}{l}T_{8}: \text { K Supplied through Mono } \\
\text { Potassium phosphate }\end{array}$ & $\begin{array}{l}14.25 \\
(0.46)\end{array}$ & $\begin{array}{c}10.72 \\
(0.285)\end{array}$ & $\begin{array}{l}88.33 \\
(2.85)\end{array}$ & $\begin{array}{l}76.74 \\
(2.04)\end{array}$ & $\begin{array}{c}164.26 \\
(5.30)\end{array}$ & $\begin{array}{c}353.62 \\
(9.40)\end{array}$ & $\begin{array}{r}2835.54 \\
(91.39)\end{array}$ & $\begin{array}{c}3320.91 \\
(88.26)\end{array}$ & 3099.40 & 3762.01 \\
\hline S.Em \pm & 0.23 & 0.2 & 1.74 & 1.53 & 2.68 & 5.07 & 45.79 & 51.27 & 53.80 & 54.71 \\
\hline $\mathrm{CD}(0.5 \%)$ & 0.71 & 0.61 & 5.29 & 4.64 & 8.14 & 15.39 & 138.90 & 155.52 & 163.20 & 165.95 \\
\hline
\end{tabular}

Figure in the parenthesis indicate the percent contribution of potassium to the total potassium 
Table.2 Potassium fixation capacity (meq $100 \mathrm{~g}^{-1}$ of soil) of soils at different depths under okra as influenced by different sources of potassium

\begin{tabular}{|c|c|c|}
\hline \multirow[t]{2}{*}{ TREATMENTS } & \multicolumn{2}{|c|}{$\begin{array}{l}\text { Potassium fixation capacity } \\
\quad\left(\mathrm{meq} 100 \mathrm{~g}^{-1} \text { of soil }\right)\end{array}$} \\
\hline & $0-15 \mathrm{~cm}$ & $15-30 \mathrm{~cm}$ \\
\hline $\mathrm{T}_{1}: \mathrm{K}$ Supplied through Muriate of potash & 0.52 & 0.69 \\
\hline $\mathrm{T}_{2}:$ K Supplied through Sulphate of potash & 0.53 & 0.71 \\
\hline $\mathbf{T}_{3}:$ K Supplied through Potassium nitrate & 0.49 & 0.66 \\
\hline $\mathbf{T}_{4}$ : K Supplied through Sulphate of potash magnesia & 0.46 & 0.62 \\
\hline $\mathrm{T}_{5}:$ K Supplied through Opifol maturation & 0.48 & 0.64 \\
\hline $\mathrm{T}_{6}: \mathrm{K}$ Supplied through Plantafol & 0.51 & 0.68 \\
\hline $\mathrm{T}_{7}:$ K Supplied through Potassium schoenite & 0.47 & 0.63 \\
\hline $\mathrm{T}_{8}$ : K Supplied through Mono potassium phosphate & 0.48 & 0.65 \\
\hline S.Em \pm & 0.002 & 0.001 \\
\hline $\mathrm{CD}(0.5 \%)$ & NS & NS \\
\hline
\end{tabular}

Table.3 Potassium release characteristics in soils under okra as influenced by different sources of potassium

\begin{tabular}{|c|c|c|c|c|c|c|c|c|c|c|c|c|c|c|c|}
\hline \multirow{2}{*}{ TREATMENT } & \multicolumn{12}{|c|}{ Successive extraction (number) with $\mathrm{1N} \mathrm{HNO}_{3}$} & Cumulative $\mathbf{K}$ & Total & CR-K \\
\hline & 1 & 2 & 3 & 4 & 5 & 6 & 7 & 8 & 9 & 10 & 11 & 12 & \multicolumn{3}{|c|}{$\left(\mathrm{mg} \mathrm{kg}^{-1}\right)$} \\
\hline$T_{1}$ : K Supplied through Muriate of potash & 295 & 198 & 118 & 72 & 35 & 28 & 15 & 9 & 6 & 6 & 6 & - & 788 & 722 & 6 \\
\hline$T_{2}:$ K Supplied through Sulphate of potash & 296 & 199 & 119 & 73 & 36 & 23 & 18 & 11 & 7 & 3 & 3 & 3 & 791 & 755 & 3 \\
\hline $\mathbf{T}_{3}:$ K Supplied through Potassium nitrate & 292 & 196 & 116 & 70 & 33 & 22 & 21 & 5 & 5 & 5 & - & & 765 & 715 & 5 \\
\hline $\begin{array}{l}T_{4}: \text { K Supplied through Sulphate of potash } \\
\text { magnesia }\end{array}$ & 288 & 192 & 112 & 66 & 29 & 15 & 7 & 7 & 7 & - & - & - & 723 & 660 & 7 \\
\hline $\mathbf{T}_{5}:$ K Supplied through Opifol maturation & 290 & 194 & 114 & 68 & 31 & 17 & 10 & 4 & 4 & 4 & - & - & 736 & 696 & 4 \\
\hline $\mathbf{T}_{6}:$ K Supplied through Plantafol & 293 & 197 & 117 & 71 & 34 & 26 & 11 & 9 & 4 & 4 & 4 & - & 770 & 726 & 4 \\
\hline $\mathbf{T}_{7}:$ K Supplied through Potassium schoenite & 289 & 193 & 113 & 67 & 30 & 16 & 10 & 3 & 3 & 3 & - & - & 727 & 697 & 3 \\
\hline $\begin{array}{l}\text { T }_{8} \text { : K Supplied through Mono potassium } \\
\text { phosphate }\end{array}$ & 291 & 195 & 115 & 69 & 32 & 18 & 13 & 7 & 7 & 7 & - & - & 754 & 705 & 7 \\
\hline Mean & & & & & & & & & & & & & 756 & 709.5 & 4.88 \\
\hline Range & & & & & & & & & & & & & 723-791 & $660-755$ & 3-7 \\
\hline
\end{tabular}




\section{Water soluble -K}

Water soluble $\mathrm{K}$ content at harvest ranged between 12.26 to $14.84 \mathrm{mg} \mathrm{kg}$. Water soluble $\mathrm{K}$ increased with the application of different source potassium. The higher content of water soluble $\mathrm{K}\left(14.84 \mathrm{mg} \mathrm{kg}^{-1}\right)$ was noted with the application of sulphate of potash. The lowest value of water soluble $\mathrm{K}$ (12.26 mg kg-1) was recorded with the treatment which received sulphate of potash magnesia. Increase in water soluble $\mathrm{K}$ might be due to increase in concentration of $\mathrm{K}$ in solution due to water soluble nature of sulphate of potash.

\section{Exchangeable $-\mathbf{K}$}

Exchangeable $\mathrm{K}$ content at harvest ranged between 78.83 to $91.87 \mathrm{mg} \mathrm{kg}^{-1}$. Exchangeable-K increased with the application of different source potassium. The highest content of Exchangeable K $(91.87 \mathrm{mg}$ $\mathrm{kg}^{-1}$ ) was noted with the application of sulphate of potash. The lowest value of Exchangeable K $\left(78.83 \mathrm{mg} \mathrm{kg}^{-1}\right)$ was recorded with the treatment which received sulphate of potash magnesia. Increase in Exchangeable $\mathrm{K}$ might be due to increase in concentration of $\mathrm{K}$ in solution due to Exchangeable nature of sulphate of potash.

\section{Non exchangeable $-\mathrm{K}$}

Non exchangeable $\mathrm{K}$ content at harvest ranged between 148.89 to $169.61 \mathrm{mg} \mathrm{kg}^{-1}$. Non exchangeable $K$ increased with the application of different source potassium. The higher content of Non exchangeable $\mathrm{K}$ (148.89 mg $\mathrm{kg}^{-1}$ ) was noted with the application of sulphate of potash. The lowest value Non exchangeable K (169.61 $\mathrm{mg} \mathrm{kg}^{-1}$ ) was recorded with the treatment which received sulphate of potash magnesia. This might be due to readily soluble nature of sulphate of potash fertiliser results in leaching which get adsorbed on clay surface in the subsurface layer. These results are in conformity with Das et al., (1997). Lowest amount of non exchangeable-K was recorded in the treatment which received sulphate of potash magnesia, this might be due to lower solubility results in less leaching loss.

\section{Mineral potassium (mg kg-1)}

The surface samples were low with respect to mineral potassium compared to sub surface depth. A cursory glance of data revealed that significantly higher amount of mineral-K was recorded in the treatment which received sulphate of potash $\left(\mathrm{T}_{2}\right)$. This might be due to readily water soluble nature of sulphate of potash fertiliser results in leaching which get fixed on clay surface in the subsurface layer. These results are in conformity with Sharma and Behera 2007. Lowest amount of non exchangeable-K was recorded in the treatment which received sulphate of potash magnesia; this might be due to lower solubility results in less leaching loss.

\section{Total potassium $\left(\mathrm{mg} \mathrm{kg}^{-1}\right)$}

The amount of total $\mathrm{K}$ which depended largely upon the clay content and type of clay mineral present in the soils and is not influenced by any cultural practices might be the cause for huge amount of total potassium present in the lower depth of soils. A cursory glance of data revealed that significant decrease in the soil total potassium was observed in the treatment $T_{4}$ compared to $T_{2}$. This may be due to lower solubility of sulphate of potash magnesia compare to sulphate of potash. The large amount of contribution/removal from the lattice clay mineral under intensive cropping system and the highest total potassium recorded in the treatment which received sulphate of potash $\mathrm{T}_{2}$ and is because the treatment received sufficient amount of $\mathrm{K}$ from external 
application to meet out the crop demand (Gangopadhyay et al., 2005).

\section{Potassium fixation capacity in soil (meq} $100 \mathrm{~g}^{-1}$ soil)

Potassium fixing capacity of surface and subsurface soils of different treatments studied under varied application of different potassium source showed wide variations in surface layer and in sub-surface depth in their capacity to fix added $\mathrm{K}$. This may be related to the $\mathrm{K}$ saturation of the exchange complex of the soils and the nature and amount of clay minerals, as evident from very low $\mathrm{K}$ fixation in $\mathrm{T}_{4}$ which received sulphate of potash magnesia and high fixation by the treatment $\mathrm{T}_{2}$ which received sulphate of potash the later having very high amount of exchangeable $\mathrm{K}$ due to higher solubility and/or more of clays and also to maintain the total equilibrium of labile and non-labile $\mathrm{K}$ pool the fixation might be high in the later treatment, However, $\mathrm{K}$ fixation was reported to be relatively higher in soils dominant in clay minerals and also $\mathrm{K}$ management practices (Ramanathan and Krishnamoorthy, 1978).

\section{Potassium release characteristics in soils}

The quantity of K-released from this form of $\mathrm{K}$ usually had a direct relation to the quantity of $\mathrm{K}$ applied to the soil and quantity of $\mathrm{K}$ taken by the crops so cultural practice has no effect on potassium release characteristics of soils. There is a need to include part of nonexchangeable $\mathrm{K}$ in the available portion while assessing $\mathrm{K}$ availability to the crops (Shivanna et al., 2014) suggested that there was a need for the use of methods of analysis which would extract $\mathrm{K}$ from the reserve pool in the soil, if the long term $\mathrm{K}$ supplying power of soil is to be assessed. The method suggested by Haylock (1956) simulates the potassium depletion pattern under intensive cropping system.

\section{Cumulative potassium release}

The results of the present study suggests that the soils, irrespective of the amount of total or the different forms of $\mathrm{K}$, released a substantial proportion of their cumulative $\mathrm{K}$ which probably included the major portion of the socalled non-exchangeable $K$, relatively easily upon depletion of the exchangeable $\mathrm{K}$ from the exchange complex. Irrespective of the treatments studied much of the total cumulative $\mathrm{K}$ was released by the end of the third or fourth extraction and the $\mathrm{K}$ release became very slow then onwards.

\section{Total step potassium}

It indicates potential of $\mathrm{K}$ release for certain period and suggests the availability of potassium for sub-sequent cropping season. The total amount of step $\mathrm{K}$ in the surface layer of soils analyzed from different treatment combinations as influenced varied levels of different organic manure application.

The amount of step $\mathrm{K}$ released in each successive extraction got reduced. Since there was no much difference between cumulative $\mathrm{K}$ and the total step $\mathrm{K}$, the same explanations from CPR may be extrapolated for total step $\mathrm{K}$ in the respective treatments as per the suggestions made by Haylock (1956).

\section{Constant rate potassium}

The constant rate $\mathrm{K}$ in the surface layer of soils different treatment combinations as influenced by application of different sources of potassium. Metson (1968) was of the opinion that CR-K of soils could be obtained after two or three extractions with the reagent, excluding the first one. However, in the present case, the CR-K for most of the treatments was obtained by the 10th /11th extraction. By this, it could be understood that irrespective of different treatment 
combinations studied, the reserve pool of available $\mathrm{K}$ was depleted very slowly in soils.

In conclusion the result of the present investigation on effect of different sources of potassium on potassium dynamics, reveals that application of sulphate of potash fertiliser increased available form of potassium and its release characteristic. Potassium fixation was highest in subsurface compare to surface layer in the treatment which received sulphate of potash.

\section{Acknowledgement}

The authors are thankful to the Department of Soil Science and Agricultural Chemistry and College of Horticulture, Bangalore, Karnataka, India, for supporting this work.

\section{References}

Black, C. A., 1965, Methods of Soil Analysis Part- II. Chemical and mineralogical properties. Agronomy Monograph No. 9, Am. Soc. Agron., Inc. Madison, Wisconsin, USA, 18-25.

Brady Delhi NC, Weil RR. The Nature and Properties of Soils, 13th Ed. Pearson, 2002.

Das, P. K., Sahu, G. C. and Das, N., 1997, Vertical distribution and release characteristics of potassium in some lateritic soils of Orissa, India. J. of Potassium Res., 13(2): 105-110.

Gangopadhyay, S. K., Sarkar, D., Sahoo, A.

K. and Das, K., 2005, Forms and distribution of potassium in some soils of Ranchi plateau. J. of Indian Soc. of Soil Sci., 53(3): 413-416.

Haylock, O. F., 1956, A method for estimating the availability of nonexchangeable potassium. Transactions $6^{\text {th }}$ Int. Congress of Soil Sci. 8: 402-408.

Jackson, M. L., 1973, Soil Chemical Analysis, Prentice Hall of India Private Limited, New Delhi. Pp. 132-148.

Knudsen, D., Peterson, G. J., and Pratt, P. F., 1982, Lithium, sodium and potassium. In methods of soil analysis part IIChemical and Microbiological properties. Ed. page, A.L., American society of Agronomy, Inc., Soil Sci. Soc. Am. Inc. Madison, Wisconsin, USA., Pp. 147-151.

Ramanathan, K. M. and Krishnamoorthy, K. K., 1978, A study of the relationship between certain soil characteristics and potassium fixation. Mysore J. Agric. Sci., 12: 69-72.

Shivanna, M., Sheelarani, S. and Anitha, E. A., 2014, Potassium release kinetics of some Western Ghats acid soils of Karnataka under paddy land use cover. Res. On crops., 15(4): 824-832.

\section{How to cite this article:}

Vimalashree, H., M. Shivanna, S. V. Patil, P. Munikrishnappa and Maruthi Prasad, B. N. 2020. Studies on the Effect of Different Sources of Potassium on Forms and Distribution, Release Kinetics and Fixation Characteristics in Alfisols. Int.J.Curr.Microbiol.App.Sci. 9(12): 877-883. doi: https://doi.org/10.20546/ijcmas.2020.912.105 